sending installation employs a microphone so constructed that the speech current is inverted with respect to frequency, so that it is unintelligible to the listener on an ordinary receiver. At the receiving end of the communication channel an equipment is used to turn the speech back to normal. From these brief details, it would appear that the system is similar to the inverted-speech method employed by the British Post Office for securing secrecy, as an alternative to the speech-scrambling method which has also been developed and used by the Post Office in long-distance radio-telephonic communication.

\section{Research on Lawns}

IT is gratifying to learn that the British Board of Greenkeeping Research will be enabled to maintain its Research Station at St. Ives, Bingley, Yorks, for a further period of five years. Vol. 10, No. 3 of the Board's Journal contains a review by the Director of the past four and a half years' work at the Station. There is also a continuation of the series of articles by Mr. I. G. Lewis, describing common grasses. Redtop (Agrostis stolonifera, L., var. gigantea, Koch) and velvet bent ( $A$. canina) are considered in the present volume. The former is somewhat coarse for fine lawns, but the latter is the queen of putting green orasses. Mr. Arthur Hill describes his experiments on lawns at Craibstone, whilst the Director of the Bingley Station, Mr. R. B. Dawson, continues his articles on "Common Weeds of Turf". Dr. T. W. Evans also contributes a paper on phosphatic fertilisers in relation to greenkeeping, and Mr. R. Gordon, of Prestwick Golf Club, writes on "A Golf Course under Seaside Conditions".

\section{Royal Society of New Zealand}

THE inaugural meeting of the newly formed Royal Society of New Zealand (hitherto called the New Zealand Institute) was held at Wellington on May 16, when the presidential address was delivered by Prof. R. Speight, professor of geology at Canterbury College, Christchurch, New Zealand. Lord Bledisloe, the Governor-General of New Zealand, in a written address to the Society, intimated His Majesty's approval of the new designation of the Dominion's chief organisation for the promotion of science. The New Zealand Institute was founded in 1867 and the fellowship of the new Society is held by forty-eight men of science. In his address, Lord Bledisloe emphasised the importance of science in solving the world's economic and social problems. Only by the further application of science in all its ramifications and a more enlightened recognition of its beneficent potentialities by the world's rulers will effective remedies for current human disorders be found. The New Zealand Institute has achieved a high prestige in a land of immeasurable opportunities for industrial and cultural expansion. It is therefore to be hoped that under its new appellation it will enjoy to an ever-increasing extent the confidence and respect of the community at large.

\section{Dorothy Temple Cross Fellowships in Tuberculosis}

The Medical Research Council has made the following awards of Dorothy Temple Cross Fellowships for 1934-35, under the terms of the benefaction in that name for research fellowships in tuberculosis : Mr. W. S. Creer, Lady Jones Orthopædic research fellow, University of Liverpool ; Mr. A. W. Franklin, chief assistant to Children's Department, St. Bartholomew's Hospital, London; Dr. P. D'A. Hart, assistant physician, University College Hospital, London ; Mr. A. Landau, house physician, Brompton Hospital, London: Mr. A. H. T. Robb-Smith, senior demonstrator of morbid anatomy, St. Bartholomew's Hospital, London. Mr. Robb-Smith's fellowship is tenable in Germany, the others at centres in the United States. In addition, the fellowship awarded last year to Dr. G. G. Kayne for work at centres in Europe has been renewed for a further period of six months.

\section{Books on Social History and Early Travel}

Messrs. Francis Edwards's Catalogue No. 572 of new and second-hand books on "History throughout the Ages" contains items of even more extended interest than the title suggests. Not only does it include source books, but also in its extra-European sections there are a number of early travel books and other works of value for their early records of ethnographical material. Among items of particular interest to the social historian is a remarkable run of the London Gazette, Nos. 1-4825, dating from November, 1665 to March 24, 1710, in thirteen folio volumes, in contemporary calf. The early numbers include notices of the Plague, indicating the rapid decrease then showing in the figures. The accounts of the Fire of London are followed by schemes for rebuilding the city. Another item of similar interest is Higden's "Polychronicon" in the Rolls Series, now partly out of print. Among official papers is a complete set of the reports of the Historical Manuscripts Commission to 1926. An editio princeps of the Nuremburg Chronicle in Gothic letter of 1493 contains 1800 woodcuts, among which appears a portrait of Pope Joan. Early travel books include Hakluyt in black letter, the "Relations" of the Jesuits in Canada (1858), Burney's South Seas, Callander's Australian voyages, Formander's "Account of the Polynesian Race", Dalrymple's voyages in the South Pacific and Kæmpfer's history of Japan.

\section{Percival Collection of Seeds of British Plants}

THE Department of Agricultural Botany of the University of Reading has acquired the Percival Collection of seeds of British plants. This collection, which took about forty years to put together, contains mounted and named seeds of more than a thousand species. Although the British flora is not completely represented, the collection is by far the most adequate in Great Britain and is invaluable for reference purposes. Prof. W. B. Brierley, professor of botany at Reading, hopes that field botanists will 